\title{
Effect of pentoxifylline on lung inflammation and gas exchange in a sepsis-induced acute lung injury model
}

I.S. Oliveira-Junior ${ }^{1,2,3,4}$, M.K.C. Brunialti ${ }^{1}$, I.H.J. Koh², V.B.C. Junqueira ${ }^{4}$ and R. Salomão ${ }^{1}$
${ }^{1}$ Divisão de Moléstias Infecciosas, ${ }^{2}$ Laboratório de Cirurgia Experimental, ${ }^{3}$ Laboratório de Mediadores Inflamatórios, ${ }^{4}$ Laboratório de Geriatria, Universidade Federal de São Paulo, São Paulo, SP, Brasil

\section{Correspondence}

\section{R. Salomão}

Laboratório de Imunologia

Divisão de Moléstias Infecciosas

\section{UNIFESP}

Rua Pedro de Toledo, 781, 15ํandar 04039-032 São Paulo, SP Brasil

Fax: +55-11-5081-5394/5571-2130

E-mail: rsalomao-dipa@pesquisa.epm.br

I.S. Oliveira-Júnior is the recipient of a post-doctoral fellowship from FAPESP (No. 03/14098-0).

$\ldots \ldots \ldots \ldots \ldots \ldots$

Received April 3, 2006 Accepted August 18, 2006 $\ldots \ldots \ldots \ldots \ldots \ldots \ldots$

\section{Abstract}

Experimental models of sepsis-induced pulmonary alterations are important for the study of pathogenesis and for potential intervention therapies. The objective of the present study was to characterize lung dysfunction (low $\mathrm{PaO}_{2}$ and high $\mathrm{PaCO}_{2}$, and increased cellular infiltration, protein extravasation, and malondialdehyde (MDA) production assessed in bronchoalveolar lavage) in a sepsis model consisting of intraperitoneal (ip) injection of Escherichia coli and the protective effects of pentoxifylline (PTX). Male Wistar rats (weighing between 270 and $350 \mathrm{~g}$ ) were injected ip with $10^{7}$ or $10^{9} \mathrm{CFU} / 100 \mathrm{~g}$ body weight or saline and samples were collected 2, 6, 12, and 24 h later ( $\mathrm{N}$ $=5$ each group). $\mathrm{PaO}_{2}, \mathrm{PaCO}_{2}$ and $\mathrm{pH}$ were measured in blood, and cellular influx, protein extravasation and MDA concentration were measured in bronchoalveolar lavage. In a second set of experiments either PTX or saline was administered $1 \mathrm{~h}$ prior to $E$. coli ip injection $(\mathrm{N}=5$ each group) and the animals were observed for $6 \mathrm{~h}$. Injection of $10^{7}$ or $10^{9} \mathrm{CFU} / 100 \mathrm{~g}$ body weight of $E$. coli induced acidosis, hypoxemia, and hypercapnia. An increased $(\mathrm{P}<0.05)$ cell influx was observed in bronchoalveolar lavage, with a predominance of neutrophils. Total protein and MDA concentrations were also higher $(\mathrm{P}<$ $0.05)$ in the septic groups compared to control. A higher tumor necrosis factor-alpha $(\mathrm{P}<0.05)$ concentration was also found in these animals. Changes in all parameters were more pronounced with the higher bacterial inoculum. PTX administered prior to sepsis reduced $(\mathrm{P}<0.05)$ most functional alterations. These data show that an $E$. coli $i p$ inoculum is a good model for the induction of lung dysfunction in sepsis, and suitable for studies of therapeutic interventions.

\section{Introduction}

In the past two decades our knowledge of the pathophysiology of acute lung injury and acute respiratory distress syndrome (ARDS)

\section{Key words}

- Acute lung injury

- Sepsis

- Inflammatory mediators

- Pentoxifylline

- Neutrophils 
Sepsis is defined as the systemic inflammatory response syndrome caused by infection (6), characterized by a high incidence of lethality $(7,8)$. Lethality in sepsis is directly associated with organ dysfunction, and ARDS secondary to sepsis represents the ultimate event (9). Sepsis results from the release of diverse mediators, amongst which proinflammatory cytokines such as tumor necrosis factor- $\alpha$ (TNF- $\alpha$ ) and interleukin-1ß (IL-1ß), which are triggered by microorganisms or products thereof and host-cell interactions (10).

Sepsis has been studied experimentally by infusion of lipopolysaccharide (LPS) and dead or live bacteria, and the cecal ligation and puncture (CLP) procedure in order to mimic features of the septic state in humans (11). Animals develop progressive bacteremia, with the release of multiple cytokines and chemokines into plasma, hypermetabolism, fever/ hypothermia, and other clinical features similar to those found in humans with sepsis (11). The main property of the lungs, gas exchange, combined with their delicate anatomical architecture, render them vulnerable during sepsis.

Various drugs blocking TNF production by LPS-activated macrophages in vitro have been used to reduce LPS toxicity in vivo, among them are pentoxifylline (PTX) and its derivative lisofylline (12). PTX is a potent phosphodiesterase inhibitor that also affects bacterial translocation (13). The hemorheologic effects of PTX are due to increased red blood cell deformability and to reduced blood viscosity. However, the primary biological activity of PTX is the suppression of TNF- $\alpha$ production, which occurs through adenylcyclase activation and increased intracellular AMP concentration (14).

We have shown that PTX protects lung dysfunction secondary to ventilatory support (ventilator-induced lung injury) by abolishing the local and systemic release of TNF- $\alpha$ and IL-1ß (15).

The goal of the present study was to establish a model of lung dysfunction in sepsis that may be useful to study the mechanisms of the disorder and to test preventive therapeutic interventions. We expected that PTX would modify the synthesis of proinflammatory mediators during sepsis-induced acute lung injury and reduce the dysfunction of the organ.

\section{Material and Methods}

The experimental protocol was reviewed and approved by the Ethics Committee of the Federal University of São Paulo, in compliance with the Guide for Care and Use of Laboratory Animals.

\section{Experimental design}

Bacteria. The bacteria used in the experiments were obtained from the mesenteric lymph nodes and Peyer's patch of animals submitted to antibiotic therapy (metronidazole and tetracycline) for 10 days. The bacteria were classified as Escherichia coli R-6 on the basis of biochemistry and morphology. Viable E. coli cells were suspended as $10^{7}$ and/ or $10^{9}$ colony forming units $(\mathrm{CFU}) / \mathrm{mL}$, and 1 $\mathrm{mL} / 100 \mathrm{~g}$ of body weight was injected intraperitoneally (ip) into the rats.

Animals. Male Wistar rats (UNIFESP, São Paulo, SP, Brazil), 270-350 g body weight, were used in this study. Control animals received saline infusion $(\mathrm{G} 1, \mathrm{~N}=20)$. Sepsis was induced by ip injection of $10^{7}(\mathrm{G} 2, \mathrm{~N}=20)$ and $10^{9} \mathrm{CFU} / 100 \mathrm{~g}$ body weight $(\mathrm{G} 3, \mathrm{~N}=20)$ of $E$. coli bacteria. The animals were maintained alive and breathing spontaneously during 2-, 6-, 12-, and 24-h periods ( $\mathrm{N}=5$ per group per time).

The effect of PTX was evaluated in animals $(\mathrm{N}=15)$ receiving $10^{7} \mathrm{CFU} / 100 \mathrm{~g}$ body weight inoculum. Animals received PTX (20 $\mathrm{mg} / \mathrm{kg}$ body weight; Pentox, Farmasa, São Paulo, SP, Brazil) or saline, injected via a tail vein, 60 min prior to the $i p$ E. coli inoculum or saline (Sham). All animals were breathing spontaneously during the 6-h period (chosen accordingly to the results of lung dysfunction 
observed in the above experiments).

\section{Experimental procedures}

In these models, the presence of sepsis was evaluated during the 6- and 12-h periods after inoculation of the bacteria, and defined by analogy to the criteria applied for humans. Each animal was considered to be septic if it satisfed at least two of the following criteria: a) decreased $\mathrm{PaO}_{2}(\leq 70 \mathrm{mmHg})$, b) rectal temperature above $38^{\circ} \mathrm{C}$ or below $36^{\circ} \mathrm{C}$, and c) increased respiratory rate $(\geq 105$ breaths $/ \mathrm{min})$.

Surgical procedures. At different times following $E$. coli injection (2, 6, 12, and $24 \mathrm{~h}$ ) the animals were anesthetized with an ip injection of $50 \mathrm{mg} / \mathrm{kg}$ sodium thiopental (Thionembutal, Abbott, Sao Paulo, SP, Brazil). Tracheostomy was performed after local anesthesia with $1 \%$ lidocaine and a 14-GA cannula was inserted into the trachea. Sterile PE50 catheters were inserted into the left internal carotid artery for blood gas sampling.

Bronchoalveolar lavage (BAL). The thoracic cavity was opened after anesthesia with sodium thiopental. The lung and structures were removed and weighed. The left lung was tied and the right lung was washed three times with $30 \mathrm{~mL} / \mathrm{kg}$ normal saline at $4^{\circ} \mathrm{C}$. Lavage fluids were kept separate and centrifuged at $400 \mathrm{~g}$ for $10 \mathrm{~min}$ at $4^{\circ} \mathrm{C}$ and the supernatants were frozen immediately on dry ice and stored at $-80^{\circ} \mathrm{C}$.

\section{Laboratory parameters}

Blood gases. Blood samples were obtained from the left internal carotid artery as described above for $\mathrm{pH}, \mathrm{PaO}_{2}$ and $\mathrm{PaCO}_{2}$ analysis (Radiometer, ABL-520, Copenhagen, Denmark).

Wet/dry weight ratio of the lungs. The lung wet/dry ratio was determined by removing and washing the right lung 2, 6, 12, and $24 \mathrm{~h}$ after ip inoculum or saline injection. Lungs were dried in an oven at $80^{\circ} \mathrm{C}$ for at least $72 \mathrm{~h}$.

Protein leakage. A 1-mL aliquot of BAL was used to measure total protein by a Lowry assay.

Cell count. Total cell concentrations in the BAL were determined in a Bürker chamber under a microscope at $100 \mathrm{X}$ magnification immediately after specimen collection.

Differential cell counts (neutrophils and macrophages) were performed after cytocentrifugation and May-Grünwald-Giemsa staining using a light microscope at 400X magnification.

Measurement of malondialdehyde (MDA). As an index of lipid peroxidation we used the generation of thiobarbituric acid reactive species (TBARS) and MDA during an acid-heating reaction as previously described (15). Briefly, the samples were mixed with $1 \mathrm{~mL}$ $10 \%$ trichloroacetic acid and $1 \mathrm{ml} 0.67 \%$ thiobarbituric acid, then heated in a boiling water bath for $15 \mathrm{~min}$. MDA was determined by absorbance at $535 \mathrm{~nm}$.

Cytokine enzyme-linked immunosorbent assay (ELISA). TNF- $\alpha$ protein concentrations in BAL were measured using a commercially available ELISA (BD OptEIA, BD Biosciences, San Diego, CA, USA) according to manufacturer instructions. Results were analyzed by spectrophotometry at $450 \mathrm{~nm}$ using an ELISA microplate reader. Threshold sensitivity was $5 \mathrm{pg} / \mathrm{mL}$.

\section{Statistical analysis}

Statistical analysis was carried out using the SPSS statistical software (SPSS 10.0, SPSS Science, Chicago, IL, USA). Data are reported as means $\pm \mathrm{SD}$. Values were compared by ANOVA followed by the Tukey-Kramer multiple comparisons test, with the level of significance set at $\mathrm{P}<0.05$.

\section{Results}

\section{Pulmonary dysfunction induced by} intraperitoneally injected $E$. coli

Blood gas evaluations. Injection of $10^{7}$ 
Figure 1. Effect of an ip Escherichia coli inoculum on blood $\mathrm{PaO}_{2}(\mathrm{~A})$ and $\mathrm{PaCO}_{2}(\mathrm{~B})$ in rats treated with $10^{7}$ and $10^{9}$ colony forming units (CFU)/100 g body weight. Samples were collected after $2,6,12$, and $24 \mathrm{~h}$ from different groups of animals that received ip injection of saline (control) and the E. coli inoculum. Data are reported as means \pm SD for 5 animals in each group. ${ }^{*} \mathrm{P}<0.05$ indicates a significant difference between $10^{7}$ and $10^{9}$ CFU/100 g body weight and the control group at the same time. $+P<0.05$ indicates a significant difference between $10^{7}$ and $10^{9}$ CFU/100 g body weight groups at the same time (ANOVA followed by the Tukey-Kramer multiple comparisons test).
(G2) and $10^{9} \mathrm{CFU} / 100 \mathrm{~g}$ body weight (G3) of $E$. coli resulted in acidosis, hypoxemia, and hypercapnia, observed for 6 and $12 \mathrm{~h}$ following the bacterial inoculum, with more pronounced alterations being found in ani-
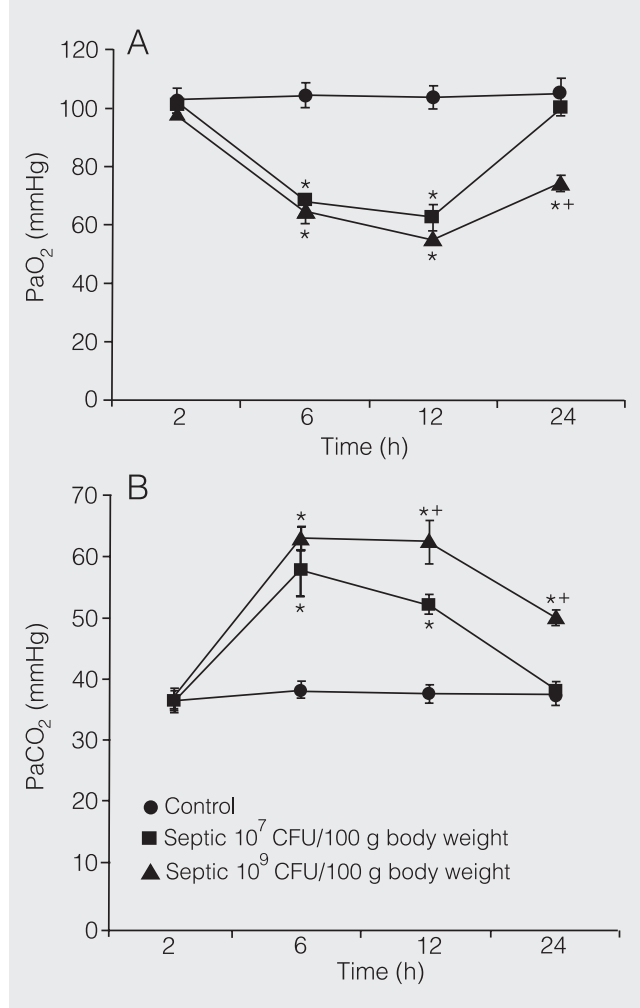

mals challenged with $10^{9} \mathrm{CFU} / 100$ g body weight than with $10^{7} \mathrm{CFU} / 100 \mathrm{~g}$ body weight (Figure 1A and B). A trend to return to baseline levels was observed in both groups after $24 \mathrm{~h}$, although the rats injected with $10^{9}$ CFU/100 g body weight continued to have abnormal values.

\section{Bronchoalveolar lavage}

Total and differential cell counts. Sepsis induced an increased total cell count in BAL fluid after 6 and $12 \mathrm{~h}$ in the groups inoculated with $10^{7}$ and $10^{9} \mathrm{CFU} / 100 \mathrm{~g}$ body weight compared to control. While total cell counts returned to baseline levels in rats injected with $10^{7} \mathrm{CFU} / 100 \mathrm{~g}$ body weight, they remained elevated in those injected with $10^{9} \mathrm{CFU}$ after $24 \mathrm{~h}$. The percentage of neutrophils in BAL increased in both septic groups 6,12 , and $24 \mathrm{~h}$ after the inoculum compared to control. In contrast, a decrease in macrophage count was observed in the groups injected with $10^{7}$ and $10^{9} \mathrm{CFU} / 100 \mathrm{~g}$ body weight after 6 and $12 \mathrm{~h}$. The percentage of macrophages remained lower in both groups after $24 \mathrm{~h}$, although trend to return to baseline levels was observed in the $10^{7} \mathrm{CFU}$

Table 1. Total cell, neutrophil and macrophage counts in the bronchoalveolar lavage fluid of rats $2,6,12$, and $24 \mathrm{~h}$ after intraperitoneal Escherichia coli injection.

\begin{tabular}{|c|c|c|c|c|}
\hline & $2 \mathrm{~h}$ & $6 \mathrm{~h}$ & $12 \mathrm{~h}$ & $24 \mathrm{~h}$ \\
\hline \multicolumn{5}{|l|}{ G1 (controls) } \\
\hline Total cells $(x$ 106/mL) & $2.0 \pm 0.7$ & $2.2 \pm 0.8$ & $2.2 \pm 1.1$ & $2.4 \pm 1.1$ \\
\hline Neutrophils (\%) & $22.8 \pm 2.8$ & $23.6 \pm 2.6$ & $23.8 \pm 1.9$ & $23.2 \pm 2.2$ \\
\hline Macrophages (\%) & $64.6 \pm 3.8$ & $63.8 \pm 3.6$ & $64.8 \pm 1.9$ & $65.4 \pm 2.3$ \\
\hline \multicolumn{5}{|c|}{ G2 (10 $\mathrm{CFU} / 100 \mathrm{~g}$ body weight) } \\
\hline Total cells $\left(\times 10^{6} / \mathrm{mL}\right)$ & $2.2 \pm 0.4$ & $4.8 \pm 0.8^{*}$ & $5.0 \pm 1.0^{*}$ & $2.8 \pm 0.8$ \\
\hline Neutrophils (\%) & $22.0 \pm 2.1$ & $47.6 \pm 4.5^{*}$ & $42.6 \pm 1.3^{*}$ & $25.8 \pm 1.9$ \\
\hline Macrophages (\%) & $66.4 \pm 3.6$ & $28.8 \pm 4.9^{*}$ & $34.2 \pm 0.8^{*}$ & $59.8 \pm 2.2^{*}$ \\
\hline \multicolumn{5}{|c|}{ G3 (109 CFU/100 g body weight) } \\
\hline Total cells $\left(\times 10^{6} / \mathrm{mL}\right)$ & $2.0 \pm 0.7$ & $5.2 \pm 0.8^{*}$ & $6.0 \pm 1.0^{*}$ & $4.8 \pm 0.8^{*+}$ \\
\hline Neutrophils (\%) & $25.8 \pm 2.4$ & $43.0 \pm 3.5^{*}$ & $43.6 \pm 2.1^{*}$ & $36.6 \pm 2.3^{*+}$ \\
\hline Macrophages (\%) & $61.0 \pm 2.3$ & $34.0 \pm 3.5^{*}$ & $28.4 \pm 2.2^{*+}$ & $40.4 \pm 2.1^{\star+}$ \\
\hline
\end{tabular}

Data are reported as means \pm SD for 5 animals in each group. CFU $=$ colony forming units. ${ }^{*} \mathrm{P}<0.05$ compared to $\mathrm{G} 1 ;{ }^{+} \mathrm{P}<0.05$ compared to $\mathrm{G} 2$ (ANOVA followed by the Tukey-Kramer multiple comparisons test). 
group (Table 1).

Wet/dry weight ratio. The changes in the lung wet/dry weight ratio measured at the various time points after saline or inoculum injection are shown in Table 2. The bacterial injections elicited a significant rise in the wet/dry ratio after $6 \mathrm{~h}(\mathrm{P}<0.0001)$ and $12 \mathrm{~h}$ $(\mathrm{P}<0.0001)$ compared to control.

Protein leakage and TBARS-MDA. Total protein concentration in lavage fluid did not differ between groups $2 \mathrm{~h}$ after ip injection, but increased in the G2 and G3 groups after 6 and $12 \mathrm{~h}$. A trend to return to baseline levels was observed in the $\mathrm{G} 2$ group after 24 h. TBARS-MDA concentration in BAL was higher in the rats receiving $E$. coli injection than in controls (Table 2).

Cytokine. Intraperitoneally injected bacteria induced TNF- $\alpha$ in the lung, detected in BAL. TNF- $\alpha$ levels higher than control were detected $2 \mathrm{~h}$ after the inoculum in rats injected with $10^{9} \mathrm{CFU}$; they increased at $6 \mathrm{~h}$, reached a peak at $12 \mathrm{~h}$, and declined $24 \mathrm{~h}$ after the inoculum. TNF- $\alpha$ levels were higher $24 \mathrm{~h}$ after $10^{9} \mathrm{CFU} / 100 \mathrm{~g}$ body weight $(73 \pm$ $12.2 \mathrm{pg} / \mathrm{mL}$ ) than after $10^{7} \mathrm{CFU} / 100 \mathrm{~g}$ body weight (35 $\pm 10.9 \mathrm{pg} / \mathrm{mL})$ E. coli (Figure 2).

\section{Protective effects of pentoxifylline}

Blood gas sampling. Administration of PTX prior to ip bacterial injection reversed the decrease in $\mathrm{PaO}_{2}(65 \pm 1.9 \mathrm{mmHg}$ (control, C-Sepsis) compared to $91 \pm 5.1 \mathrm{mmHg}$ (PTX + Sepsis)) and partially reversed the increase in $\mathrm{PaCO}_{2}$ induced by ip injection of E. coli $(57 \pm 1.6 \mathrm{mmHg}$ (C-Sepsis) compared to $45 \pm 4.5 \mathrm{mmHg}$ (PTX + Sepsis)) observed 6 h after E. coli infusion (Figure 3 ).

\section{Biological determinations}

Total and differential cell counts. PTX infusion decreased cellularity and the percentage of neutrophils and increased the percentage of macrophages observed in the PTX + Sepsis group (Table 3).

Oxidative stress. MDA concentrations in BAL decreased in the PTX + Sepsis group compared to the C-Sepsis group (Table 3).

Wet/dry weight ratio. The changes in the wet/dry weight ratio of the lung measured

\begin{tabular}{|c|c|c|c|c|}
\hline & $2 \mathrm{~h}$ & $6 \mathrm{~h}$ & $12 \mathrm{~h}$ & $24 \mathrm{~h}$ \\
\hline \multicolumn{5}{|c|}{ Total protein (mg/mL) } \\
\hline G1 & $2.2 \pm 0.8$ & $2.8 \pm 0.8$ & $3.4 \pm 1.1$ & $3.2 \pm 1.3$ \\
\hline G2 & $3.2 \pm 1.6$ & $21.2 \pm 0.4^{\star}$ & $21.8 \pm 0.4^{\star}$ & $6.8 \pm 1.1^{\star}$ \\
\hline G3 & $5.2 \pm 1.8^{*}$ & $26.2 \pm 0.8^{*+}$ & $23.4 \pm 0.5^{\star+}$ & $22.2 \pm 0.8^{*+}$ \\
\hline \multicolumn{5}{|c|}{ TBARS-MDA (ng/mL) } \\
\hline G1 & $112.2 \pm 3.3$ & $111.2 \pm 5.2$ & $110.2 \pm 4.8$ & $112.4 \pm 5.1$ \\
\hline G2 & $119.4 \pm 0.9^{*}$ & $424.6 \pm 3.4^{*}$ & $437.2 \pm 8.6^{*}$ & $383.2 \pm 15.1^{*}$ \\
\hline G3 & $224.4 \pm 2.1^{\star+}$ & $469.8 \pm 13.4^{*+}$ & $450.2 \pm 14.9^{\star}$ & $421.4 \pm 22.2^{\star+}$ \\
\hline \multicolumn{5}{|c|}{ W/D weight ratio $(\mathrm{g})$} \\
\hline G1 & $9.0 \pm 1.0$ & $9.7 \pm 5.7$ & $10.2 \pm 1.3$ & $10.6 \pm 1.4$ \\
\hline G2 & $10.4 \pm 0.3$ & $13.6 \pm 1.2^{*}$ & $13.2 \pm 0.8^{\star}$ & $11.3 \pm 1.3$ \\
\hline G3 & $9.4 \pm 0.8$ & $14.1 \pm 1.9^{*}$ & $15.2 \pm 1.1^{\star+}$ & $11.2 \pm 0.5$ \\
\hline
\end{tabular}

Data are reported as means $\pm \mathrm{SD}$ for 5 animals in each group. G1 = control; G2 $=10^{7} \mathrm{CFU}$ E. coli $/ 100 \mathrm{~g}$ body weight; G3 $=10^{9} \mathrm{CFU}$ E. coli $/ 100 \mathrm{~g}$ body weight.

${ }^{*} \mathrm{P}<0.05$ compared to $\mathrm{G} 1 ;{ }^{+} \mathrm{P}<0.05$ compared to G2 (ANOVA followed by the Tukey-Kramer multiple comparisons test). 


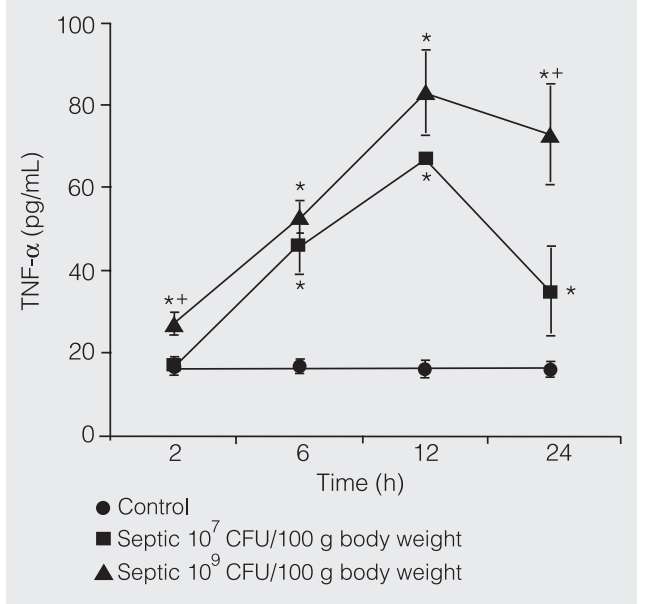

Figure 2. Effect of an ip Escherichia coli inoculum on tumor necrosis factor-alpha (TNF- $\alpha$ ) in bronchoalveolar lavage of rats treated with $10^{7}$ and $10^{9}$ colony forming units (CFU)/100 g body weight. Bronchoalveolar lavage was collected after 2, 6, 12, and $24 \mathrm{~h}$ from different groups of animals that received an ip injection of saline (control) or the E. coli inoculum, and TNF levels were measured by ELISA. Data are reported as mean \pm SD for 5 animals in each group. ${ }^{*} \mathrm{P}<0.05$ indicates a significant difference between $10^{7}$ and $10^{9} \mathrm{CFU} / 100 \mathrm{~g}$ body weight and control group at the same time. ${ }^{+} \mathrm{P}<0.05$ indicates a significant difference between $10^{7}$ and $10^{9} \mathrm{CFU} / 100 \mathrm{~g}$ body weight groups at the same time (ANOVA followed by the Tukey-Kramer multiple comparisons test).

Table 3. Total cells, neutrophils, macrophages, total proteins, and thiobarbituric acid reactive speciesmalondialdehyde (TBARS-MDA) in bronchoalveolar lavage fluid, and wet/dry (W/D) weight ratio of spontaneous breathing rats, measured at the end of $6 \mathrm{~h}$.

\begin{tabular}{lrrr}
\hline & Control-Sham & Control-Sepsis & PTX + Sepsis \\
\hline Total cells $\left(\times 10^{6} / \mathrm{mL}\right)$ & $2.4 \pm 0.5$ & $6.0 \pm 0.7^{*}$ & $3.2 \pm 0.4^{*}$ \\
Neutrophils $(\%)$ & $9.0 \pm 2.0$ & $58.2 \pm 3.3^{*}$ & $12.0 \pm 1.4^{*}$ \\
Macrophages $(\%)$ & $64.2 \pm 2.2$ & $12.2 \pm 1.1^{*}$ & $60.4 \pm 3.3^{*}$ \\
Total protein $(\mathrm{mg} / \mathrm{mL})$ & $4.2 \pm 0.3$ & $21.2 \pm 1.3^{*}$ & $6.5 \pm 0.7^{*+}$ \\
TBARS-MDA $(\mathrm{ng} / \mathrm{mL})$ & $117.6 \pm 1.8$ & $469.8 \pm 36.8^{*}$ & $281.4 \pm 48.4^{*+}$ \\
W/D weight ratio $(\mathrm{g})$ & $7.6 \pm 0.5$ & $11.2 \pm 1.1^{*}$ & $8.6 \pm 0.5^{*+}$ \\
\hline
\end{tabular}

Data are reported as means \pm SD for 5 animals in each group. Animals received saline (Control) or $20 \mathrm{mg} / \mathrm{kg}$ body weight pentoxifylline (PTX) 60 min prior to ip E. coli inoculum (Sepsis) or saline (Sham).

${ }^{*} \mathrm{P}<0.05$ compared to control-sham; ${ }^{+} \mathrm{P}<0.05$ compared to control-sepsis (ANOVA followed by the TukeyKramer multiple comparisons test).
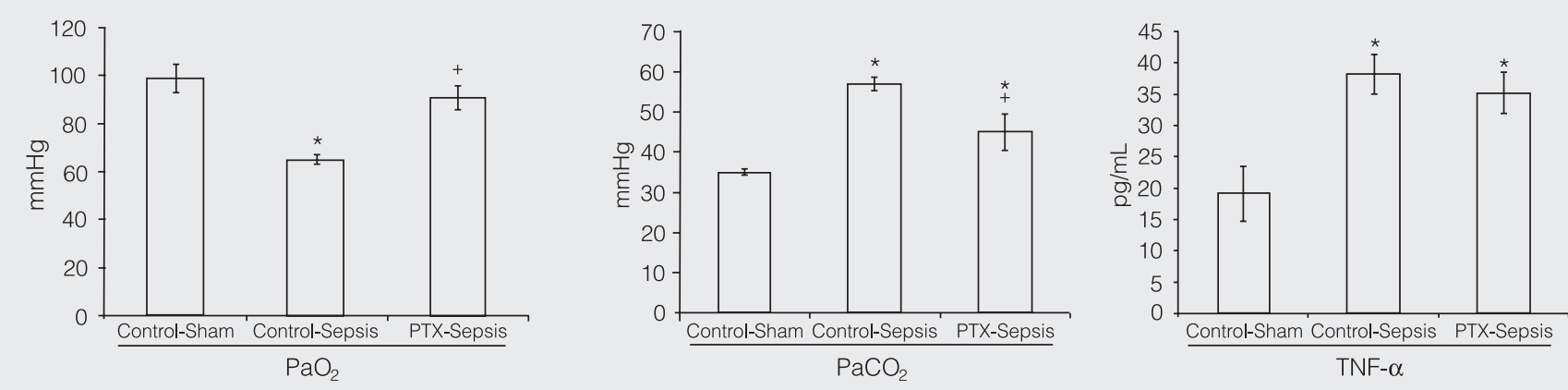

Figure 3. Effects of pentoxifylline (PTX) on blood gases exchanges $\left(\mathrm{PaO}_{2}\right.$ and $\left.\mathrm{PaCO}_{2}\right)$ and on TNF- $\alpha$ levels in bronchoalveolar lavage in sepsisinduced acute lung injury. Rats received PTX or saline $1 \mathrm{~h}$ prior to the ip injection of $10^{7} \mathrm{CFU} / 100 \mathrm{~g}$ body weight. Blood samples and bronchoalveolar lavage were collected $6 \mathrm{~h}$ after bacterial inoculation. TNF- $\alpha$ levels were measured by ELISA. Data are reported as mean \pm SD for 5 animals. ${ }^{*} \mathrm{P}<0.05$ compared to Control-Sham; ${ }^{+} \mathrm{P}<0.05$ compared to Control-Sepsis (ANOVA followed by the Tukey-Kramer multiple comparisons test). 
after PTX or inoculum injection are shown in Table 3.

Cytokine. TNF- $\alpha$ levels were significantly increased in the C-Sepsis group (38.2 \pm 3.11 $\mathrm{pg} / \mathrm{mL}$ ) compared to the C-Sham group (19 $\pm 4.39 \mathrm{pg} / \mathrm{mL}$ ). The levels did not decrease significantly in the PTX + Sepsis group compared to the C-Sepsis group (Figure 3).

\section{Discussion}

The present results show an extensive pulmonary dysfunction following $i p$ injected E. coli. Pulmonary dysfunction complicating sepsis, indicated by ARDS, is known to be a major factor affecting morbidity and mortality of septic patients (16). Thus, the development of a sepsis model with welldefined respiratory dysfunction is important both as a tool to understand the pathogenesis of the disorder and as a model to test potential interventions. Different experimental approaches have been used to study pulmonary dysfunction in sepsis, among them CLP (17) and injection of LPS (18). The CLP model has been used very often because it mimics human peritoneal sepsis (17). Salkowski et al. (19) reported that the height of intraperitoneal inflammation and lung dysfunction is related to the number of cecal punctures. However, Malloy et al. (20) showed that this procedure did not result in severe pulmonary edema since total alveolar protein measurements and wet/dry ratios were similar in the sham and septic groups. LPS toxicity has been used for models of acute lung injury, administered both as intravenous injection and as tracheal instillation. Direct intravenous injection induces elevations in catecholamine levels in the pulmonary and systemic circulation as well as a rapid increase in neutrophil number and proinflammatory cytokine expression in the lungs (21). Fan et al. (22) demonstrated that LPS alone caused a small increase in BAL fluid neutrophil counts, but animals subjected to shock before LPS exhibited a fur- ther three-fold increase in neutrophil numbers. Intratracheal administration of LPS increased protein and cytokine concentrations and inflammatory cells in BAL fluid (23). Studies with LPS have led to important breakthroughs in our understanding of the pathophysiology of sepsis, but they are restricted to the use of a toxin rather than a live bacterium. Despite the increasing interest in CLP, we considered it appropriate to use ip injection in our study in order to avoid the inflammatory response induced by the surgical procedure required in that model.

We described here the lung derangements seen in rats injected $i p$ with E. coli. Pulmonary dysfunction was characterized by low $\mathrm{PaO}_{2}$ and high $\mathrm{PaCO}_{2}$ saturation in blood, and increased cellular infiltration, protein extravasation, and MDA production assessed in BAL.

Increased cellularity was observed in $\mathrm{BAL}$, with a predominance of neutrophils in septic animals. Accordingly, an increased MDA concentration was found in BAL from these animals, probably resulting from increased neutrophil influx, enhanced cellular activity, and increased reactive oxygen/nitrogen species production. Interestingly, all alterations observed were more profound and long-lasting with the higher $\left(10^{9} \mathrm{CFU} /\right.$ $100 \mathrm{~g}$ body weight) than with the lower $\left(10^{7}\right.$ CFU/100 g body weight) inoculum.

The involvement of inflammatory mediators in lung dysfunction was assessed by the measurement of TNF- $\alpha$, a pro-inflammatory cytokine, in BAL. Levels of TNF- $\alpha$ were higher in septic animals than in controls. TNF- $\alpha$ has been implicated as an important mediator in ARDS because of its effect on endothelial cells as well as on innate immunity cells. This cytokine has been implicated in the activation of endothelial cells with secretion of secondary mediators, including platelet-aggregating factor and nitric oxide, and expression of adhesion molecules as well as of pro-coagulant factors (24). Furthermore, it may enhance mon- 
ocyte and neutrophil activity in an autocrine/ paracrine fashion $(25,26)$.

The potential use of this model for intervention therapy was assessed by testing the protective effect of PTX. PTX is a phosphodiesterase inhibitor that has been shown to decrease TNF- $\alpha$ levels and to down-regulate neutrophil activation, probably by increasing intracellular cyclic AMP (27). We have previously shown that PTX protects rats from lung injury induced by ventilation with a high tidal volume (15).

Since Chalkiadakis et al. (28) reported the beneficial effects of PTX during sepsis in 1985, several studies have demonstrated that the administration of PTX during sepsis or endotoxic shock preserves cardiac output and small intestine microvascular blood flow (29), reduces multiple organ damage (30), prevents TNF- $\alpha$-induced lung injury (31), improves tissue oxygen extraction capability (32) and oxygen use (33), and increases the survival of septic animals (34). Although the precise mechanisms responsible for the beneficial effects of PTX in sepsis remain unknown, studies have indicated that PTX increases intracellular cAMP levels, which increase the activity of protein kinase A (cAMP-dependent kinase) and up-regulate the cAMP-dependent response of elementbinding protein (a nuclear factor) to downregulate the expression of TNF- $\alpha$ messenger RNA (35). In addition to the down-regulation of TNF- $\alpha$ by PTX, Voisin et al. (36) reported that pretreatment with this agent in a rat model of $E$. coli bacteremia prevented the increase of IL- 1 and IL-6.

We found that pretreatment with PTX could attenuate most of the sepsis-induced functional lung alterations. Whether such effect would be observed if PTX were administered after the insult requires further investigation.

We found no statistically significant difference in the BAL levels of TNF- $\alpha$ when comparing C-Sepsis and PTX + Sepsis animals. This may be due to the PTX concentration used in the study. Also, an effect on TNF- $\alpha$ levels at earlier time points cannot be excluded. Alternatively, PTX could afford protection by its effects on inflammatory cells. Studies evaluating the effects of PTX on adhesion molecule expression have shown decreased P-selectin expression after hemorrhagic shock and decreased proinflammatory cytokine-induced ICAM-1 expression in human pulmonary epithelial cells and polymorphonuclear leukocytes $(11,17,37)$.

The present study shows that an E. coli ip inoculum provides a good model for the induction of lung dysfunction in sepsis, suitable for studies of therapeutic interventions.

\section{Acknowledgments}

The authors are grateful to Ana Maria Alvin Liberatore and Marjorie Yuri Taki for the bacterial culture.

\section{References}

1. Ashbaugh DG, Bigelow DB, Petty TL, Levine BE. Acute respiratory distress in adults. Lancet 1967; 2: 319-323.

2. Villar J, Slutsky AS. Is the outcome from acute respiratory distress syndrome improving? Curr Opin Crit Care 1996; 2: 79-87.

3. Milberg JA, Davis DR, Steinberg KP, Hudson LD. Improved survival of patients with acute respiratory distress syndrome (ARDS): 19831993. JAMA 1995; 273: 306-309.

4. Villar J, Perez-Mendez L, Kacmarek RM. Current definitions of acute lung injury and the acute respiratory distress syndrome do not reflect their true severity and outcome. Intensive Care Med 1999;
25: 930-935.

5. Villar J, Slutsky AS. Ventilatory management of sepsis-associated respiratory distress syndrome. In: Fein A, Abraham EM, Balk RA, Bernard GR, Bone RC, Dantzker DR, et al. (Editors), Sepsis and multiorgan failure. Baltimore: Williams \& Wilkins; 1997. p 453-461.

6. Bone RC, Sibbald WJ, Sprung CL. The ACCP-SCCM consensus conference on sepsis and organ failure. Chest 1992; 101: 14811483.

7. Martin GS, Mannino DM, Eaton S, Moss M. The epidemiology of sepsis in the United States from 1979 through 2000. N Engl J Med 
2003; 348: 1546-1554.

8. Angus DC, Linde-Zwirble WT, Lidicker J, Clermont G, Carcillo J, Pinsky MR. Epidemiology of severe sepsis in the United States: analysis of incidence, outcome, and associated costs of care. Crit Care Med 2001; 29: 1303-1310.

9. Esteban A, Anzueto A, Alia I, Gordo F, Apezteguia C, Palizas F, et al. How is mechanical ventilation employed in the intensive care unit? An international utilization review. Am J Respir Crit Care Med 2000; 161: 1450-1458.

10. Dreyfus D, Soler P, Basset G, Saumon G. High inflation pressure pulmonary edema: respective effects of high airway pressure, high tidal volume and positive end-expiratory pressure. Am Rev Respir Dis 1988; 137: 1159-1164.

11. Alves-Filho JC, Tavares-Murta BM, Barja-Fidalgo C, Benjamim CF, Basile-Filho A, Arraes SM, et al. Neutrophil function in severe sepsis. Endocr Metab Immune Disord Drug Targets 2006; 6: 151-158.

12. Rice GC, Rosen J, Weeks R, Michnick J, Bursten S, Bianco JA, et al. CT-1501R selectively inhibits induced inflammatory monokines in human whole blood ex vivo. Shock 1994; 1: 254-266.

13. Kocdor MA, Kocdor H, Gulay Z, Gokce O. The effects of pentoxifylline on bacterial translocation after intestinal obstruction. Shock 2002; 18: 148-151.

14. Colson A, Willems B, Thissen JP. Inhibition of TNF-alpha production by pentoxifylline does not prevent endotoxin-induced decrease in serum IGF-I. J Endocrinol 2003; 178: 101-109.

15. Oliveira-Junior IS, Pinheiro BV, Silva ID, Salomao R, Zollner RL, Beppu OS. Pentoxifylline decreases tumor necrosis factor and interleukin-1 during high tidal volume. Braz J Med Biol Res 2003; 36 : 1349-1357.

16. Stapleton RD, Wang BM, Hudson LD, Rubenfeld GD, Caldwell ES, Steinberg KP. Causes and timing of death in patients with ARDS. Chest 2005; 128: 525-532.

17. Koo DJ, Yoo P, Cioffi WG, Bland KI, Chaudry IH, Wang P. Mechanism of the beneficial effects of pentoxifylline during sepsis: maintenance of adrenomedullin responsiveness and downregulation of proinflammatory cytokines. J Surg Res 2000; 91: 70-76.

18. Ohtsuka H, Higuchi $T$, Matsuzawa $H$, Sato $H$, Takahashi $K$, Takahashi J, et al. Inhibitory effect on LPS-induced tumor necrosis factor in calves treated with chlorpromazine or pentoxifylline. $J$ Vet Med Sci 1997; 59: 1075-1077.

19. Salkowski CA, Detore G, Franks A, Falk MC, Vogel SN. Pulmonary and hepatic gene expression following cecal ligation and puncture: monophosphoryl lipid A prophylaxis attenuates sepsis-induced cytokine and chemokine expression and neutrophil infiltration. Infect Immun 1998; 66: 3569-3578.

20. Malloy JL, Veldhuizen RA, McCormack FX, Korfhagen TR, Whitsett JA, Lewis JF. Pulmonary surfactant and inflammation in septic adult mice: role of surfactant protein A. J Appl Physiol 2002; 92: 809-816.

21. Abraham E, Kaneko DJ, Shenkar R. Effects of endogenous and exogenous catecholamines on LPS-induced neutrophil trafficking and activation. Am J Physiol 1999; 276: L1-L8.
22. Fan J, Marshall JC, Jimenez M, Shek PN, Zagorski J, Rotstein OD. Hemorrhagic shock primes for increased expression of cytokineinduced neutrophil chemoattractant in the lung: role in pulmonary inflammation following lipopolysaccharide. J Immunol 1998; 161: 440-447.

23. Altemeier WA, Matute-Bello G, Gharib SA, Glenny RW, Martin TR, Liles WC. Modulation of lipopolysaccharide-induced gene transcription and promotion of lung injury by mechanical ventilation. $J$ Immunol 2005; 175: 3369-3376.

24. Harrison DG. Cellular and molecular mechanisms of endothelial cell dysfunction. J Clin Invest 1997; 100: 2153-2157.

25. Grutkoski PS, D'Amico R, Ayala A, Simms HH. Tumor necrosis factor-alpha-stimulated polymorphonuclear leukocytes suppress migration and bactericidal activity of polymorphonuclear leukocytes in a paracrine manner. Crit Care Med 2002; 30: 591-597.

26. MacDonald J, Galley HF, Webster NR. Oxidative stress and gene expression in sepsis. Br J Anaesth 2003; 90: 221-232.

27. Noel P, Nelson S, Bokulic R, Bagby G, Lippton H, Lipscomb G, et al. Pentoxifylline inhibits lipopolysaccharide-induced serum tumor necrosis factor and mortality. Life Sci 1990; 47: 1023-1029.

28. Chalkiadakis GE, Kostakis A, Karayannacos PE, Chalkiadakis ME, Sgouromali S, Giamarellou H, et al. Pentoxifylline in the treatment of experimental peritonitis in rats. Arch Surg 1985; 120: 1141-1144.

29. Steeb GD, Wilson MA, Garrison RN. Pentoxifylline preserves smallintestine microvascular blood flow during bacteremia. Surgery 1992; 112: 756-763.

30. Harada H, Ishizaka A, Yonemaru M, Mallick AA, Hatherill JR, Zheng $\mathrm{H}$, et al. The effects of aminophylline and pentoxifylline on multiple organ damage after Escherichia coli sepsis. Am Rev Respir Dis 1989; 140: 974-980.

31. Lilly CM, Sandhu JS, Ishizaka A, Harada H, Yonemaru M, Larrick JW, et al. Pentoxifylline prevents tumor necrosis factor-induced lung injury. Am Rev Respir Dis 1989; 139: 1361-1368.

32. Zhang $\mathrm{H}$, Spapen $\mathrm{H}$, Benlabed $\mathrm{M}$, Nguyen DN, Buurman WA, Vincent JL. Pentoxifylline improves the tissue oxygen extraction capabilities during endotoxic shock. Shock 1994; 2: 90-97.

33. Bacher A, Mayer N, Klimscha W, Oismuller C, Steltzer H, Hammerle A. Effects of pentoxifylline on hemodynamics and oxygenation in septic and nonseptic patients. Crit Care Med 1997; 25: 795-800.

34. Schade UF. Pentoxifylline increases survival in murine endotoxin shock and decreases formation of tumor necrosis factor. Circ Shock 1990; 31: 171-181.

35. Maier RV. Pentoxifylline in sepsis. Arch Surg 1998; 133: 466.

36. Voisin L, Breuille D, Ruot B, Ralliere C, Rambourdin F, Dalle M, et al. Cytokine modulation by PX differently affects specific acute phase proteins during sepsis in rats. Am J Physiol 1998; 275: R1412-R1419.

37. Krakauer T. Pentoxifylline inhibits ICAM-1 expression and chemokine production induced by proinflammatory cytokines in human pulmonary epithelial cells. Immunopharmacology 2000; 46: 253261. 